\title{
PENETAPAN MUTU EKSTRAK ETANOL KULIT BATANG BANYURU (Pterospermum celebicum, Miq.) SEBAGAI BAHAN BAKU SEDIAAN HERBAL TERSTANDAR
}

\author{
Asnah Marzuki ${ }^{1}$, Rahim ${ }^{2}$, Rita $^{2}$ \\ ${ }^{1}$ Laboratorium Kimia Farmasi, Fakultas Farmasi, Universitas Hasanuddin, \\ Jalan Perintis Kemerdekaan Km 10, Tamalanrea, Makassar \\ ${ }^{2}$ Laboratorium Farmakognosi-Fitokimia, FakultasFarmasi, ,Universitas Hasanuddin, \\ Jalan Perintis Kemerdekaan Km 10, Tamalanrea, Makassar \\ *Email: asnah_marzuki@yahoo.com
}

\begin{abstract}
The research of the determination of quality Banyuru (Pterospermum celebicum, Miq) bark ethanol extract, comes from the Bantaeng, Malino and Pare-Pare, a specific plant and has been used as a traditional plant in South Sulawesi. This research aims to make as a raw material preparation standardized herbal extracts, using quality standards as a parameter. Standardized herbal extracts which include extracts organoleptic testing, with the results showing all EKBB dark brown extract, astringent taste, textured powder and has a characteristic odor, assay compound EKBB extract water soluble Bantaeng origin $13.48 \%$ and the concentration of substances soluble ethanol $1.84 \%$. Malino origin extracts compound content of water-soluble compound content is $14.89 \%$ and $3.61 \%$ soluble ethanol. EKBB compound content origin Pare-Pare $14.76 \%$ water soluble and ethanol soluble compound content is $2.48 \%$. Profile of chemical compounds each extract is done with methods that extract EKBB KLT- Densitofotometrik shows that the area Bantaeng, Malino and Pare-Pare contain flavonoid compounds, flavonoid compounds characterized by staining blue on spraying with reagent sitroborat. The average total flavonoid compounds Bantaeng EKBB 1.10\%, 1.06\% and Malino Pare-Pare 1.05\% calculated as quercetin.
\end{abstract}

Keywords: Banyuru (Pterospermum celebicum, Miq), Quality, Bark, Ethanol Extract.

\begin{abstract}
ABSTRAK
Penelitian penetapan mutu ekstrak etanol kulit batang Banyuru (Pterospermum celebicum, Miq), telah dilakukan, yang berasal dari daerah Bantaeng, Malino dan ParePare, yang merupakan tanaman spesifik. digunakan sebagai tanaman tradisional Sulawesi Selatan. Penelitian ini bertujuan menjadikan sebagai bahan baku ekstrak sediaan herbal terstandar, menggunakan standar mutu sebagai parameter. Ekstrak herbal terstandar yang meliputi pengujian organoleptik ekstrak, dengan hasil menunjukkan semua ekstrak EKBB berwarna coklat tua, rasa sepat, bertekstur serbuk dan memiliki bau yang khas, pengujian kadar senyawa ekstrak EKBB asal Bantaeng yang larut air 13,48\% dan kadar senyawa yang larut etanol $1,84 \%$. Kadar senyawa ekstrak asal Malino yang larut air 14,89\% dan kadar senyawa yang larut etanol 3,61\%. Kadar senyawa EKBB asal Pare-Pare yang larut air $14,76 \%$ dan kadar senyawa yang larut etanol 2,48\%. Profil senyawa kimia masing-masing ekstrak dilakukan dengan metode KLT- Densitofotometrik yaitu ekstrak
\end{abstract}


EKBB menunjukkan bahwa daerah Bantaeng, Malino dan Pare-Pare mengandung senyawa golongan flavonoid, senyawa golongan flavonoid ditandai dengan bercak noda berwarna biru pada penyemprotan dengan reagen sitroborat. Total rata-rata kandungan flavonoid senyawa EKBB Bantaeng 1,10\%, Malino 1,06\% dan Pare-Pare 1,05\% dihitung sebagai kuersetin.

Kata Kunci : Banyuru (Pterospermum celebicum, Miq), Standar mutu, Kulit Batang, Ekstrak Etanol.

\section{PENDAHULUAN}

Tumbuhan tropis mempunyai kemampuan merekayasa beraneka ragam senyawa kimia yang mempunyai berbagai bioaktivitas yang menarik dan merupakan salah satu akibat mekanisme pertahanan diri terhadap ancaman lingkungan (1), karena pada umumnya hidup di bawah kondisi lingkungan yang keras,. baik faktor iklim maupun gangguan dari herbivora. serangga, dan hama penyakit. Untuk itu, tumbuhan tropis dapat menghasilkan senyawa-senyawa kimia alami yang bersifat pestisida. insektisida, antifungi, dan sitotosik . Tumbuhan familia Sterculiaceae telah berhasil diisolasi beberapa senyawa kimia dan berbagai golongan antara lain alkaloid. flavanoid, polifenol, triterpenoid dan tanin yang potensial sebagai antimikroba, antitumor, dan pestisida $(2,3)$. Spesies Sterculiaceae telah digunakan dalam pengobatan tradisional, seperti pada spesies yang telah diskrining yaitu Cola Greenwayi, Cola natalensis, Dombeya burgessiae, Dombeya cymosa dan Hermannia depressa, diperoleh ekstrak yang mengandung alkaloid, cardiac glikosida, sianogenik glikosida, saponin dan tannin. Ekstraknya telah diskrining untuk aktivitas anti inflamasi dan antibakteri dengan menggunakan penentuan terhadap penghambatan siklo oksigenase - 1 ( COX -1 ) dari penentuan inhibisi dan penentuan mikrodilusi antibakteri. Penetapan Bioautogravi menggunakan Staphylococcus aureus yang digunakan untuk mendeteksi keberadaan komponen antibakteri, di isolasi dan diidentifikasi sebagai asam lemak (4).

Flavanoid merupakan senyawa polifenol, sifatnya sebagai senyawa fenol yaitu agak asam dan dapat larut dalam basa, dan karena merupakan senyawa polihidroksi (gugus hidroksil) maka juga bersifat polar sehingga dapat larut dalan pelarut polar seperti etanol, aseton, air, butanol, dimetil sulfoksida. Disamping itu dengan adanya gugus glikosida yang terikat pada gugus flavonoid sehingga cenderung menyebabkan flavonoid mudah larut dalam air. (5). Salah satu genusnya telah dilaporkan yaitu tumbuhan Banyuru (Pterospermum celebicum, Miq) dan telah diidentifikasi pada kulit batangnya mengandung senyawa polifenol, flavonoid, dan saponin,yang sangat banyak, sehingga kulit batang jenis tumbuhan ini berpotensi untuk berbagai kemungkinan bahan obat, tannin, polifenol dan flavanoid, senyawa-senyawa metabolit sekunder ini memiliki bioaktivitas menarik dan mempunyai efek terapetik yang tepat juga telah dimanfaatkan sebagai obat tradisional secara luas oleh masyarakat khususnya di Sulawesi Selatan dan mempunyai khasiat sebagai obat yang mampu mengobati penyakit disentri, luka pada gusi dan gatal pada kulit dan sebagai antiseptik, walaupun kayunya digunakan sebagai bahan bangunan dan kulit batang digunakan sebagai pewarna (6). Pengembangan obat tradisional menjadi ekstrak yang terstandar atau fitofarmaka, dengan melalui tahap standardisasi untuk menjamin kejelasan dan kesamaan bahan yang terkandung di dalam sediaan dari bahan alam sehingga diharapkan mempunyai efek farmakologi yang tetap dari waktu ke waktu.

Standardisasi obat herbal merupakan rangkaian proses yang melibatkan berbagai metode analisis kimiawi berdasarkan kandungan senyawa ekstrak, analisis fisik dan mikrobiologi berdasarkan kriteria umum keamanan (toksikologi) terhadap suatu ekstrak alam (tumbuhan obat) (7). Biasanya obat tradisional dibuat dalam bentuk ekstrak karena 
tanaman obat tidak lagi praktis jika digunakan dalam bentuk bahan utuh (simplisia). Ekstrak tersebut bisa dalam bentuk ekstrak kering, ekstrak kental, dan ekstrak cair yang proses pembuatannya disesuaikan dengan bahan aktif yang dikandung serta maksud penggunaannya, apakah dibuat menjadi sediaan dalam bentuk kapsul, tablet, cairan obat dalam, pil, dan lain-lain (8).

Standardisasi obat herbal meliputi dua aspek, yaitu aspek parameter spesifik dan aspek parameter non spesifik. Aspek parameter spesifik yakni terutama yang berkaitan dengan senyawa atau golongan senyawa yang mempengaruhi aktivitas farmakologis. Analisis kimia yang dilibatkan ditujukan untuk analisa kualitatif dan kuantitatif terhadap senyawa aktif. Aspek parameter non spesifik berfokus pada aspek kimia, mikrobiologi dan fisis yang akan mempengaruhi keamanan konsumen dan stabilitas, misalnya pengaruh lingkungan tempat tumbuh, adanya pencemar logam berat, pestisida di dalam air dan tanah, kontaminasi selama penanganan pasca panen, peralatan yang digunakan selama proses akan mempengaruhi ada tidaknya dan jumlah bakteri, jamur, pestisida, dan logam berat di dalam ekstrak jika terakumulasi dalam jangka panjang (9).

Berdasarkan uraian di atas, dilakukan penentuan mutu standardisasi spesifik ekstrak kulit batang banyuru (Pterospermum Celebicum, Miq.), agar khasiat dan stabilitasnya dapat terjamin saat dijadikan sebagai bahan obat. Adapun tujuan dari penelitian ini untuk memperoleh nilai standarisasi sebagai parameter mutu serta penentuan aktivitasnya terhadap penyakit infeksi.

\section{TINJAUAN PUSTAKA}

\section{Uraian Umum Banyuru ( Pterospermum Celebicum Miq).}

Klasifikasi tumbuhan (6).

Divisi : Spermatophyta

Sub divisi : Angiospermae

Kelas : Dicotyledonae

Sub kelas : Sympetalae

Bangsa : Malvales

Suku : Sterculiaceae

Marga : Pterospermum

Spesies : Pterospermum celebicum Miq

Tumbuhan Pterospermum Celebicum, tumbuh tersebar di hutan-hutan primer atau tumbuh melimpah secara lokal di hutan-hutan sekunder dan terutama pada pinggir sungai, pada tanah aluvial, tumbuh hingga mencapai ketinggian $1400 \mathrm{~m}$ dari permukaan laut. Merupakan salah satu tumbuhan tropis yang spesifik di Sulawesi Selatan, berupa pohon berukuran sedang hingga besar, tingginya mencapai 45 meter dan berdiameter hingga 100$120 \mathrm{~cm}$. Mempunyai daun berwarna hampir coklat kemerahan pada bagian permukaan bawah dan dilapisi stipula. Permukaan kulit batang bersisik dan mempunyai bunga dan buah. Genus Pterospermum mempunyai 40 spesies, terdistribusi di India, Burma, China selatan, Thailand dan seluruh wilayah Malaysia. Tumbuhan Sterculiaceae terdiri dari 58 genus dan sekitar 700 spesies. Berdasarkan laporan ASEAN Regional Centre for Biodiversity Conservation (ARCBC), dalam Checklist of Medicinal Plants In Southeast Asia, tumbuhan Pterospermum Celebicum terdistribusi di Indonesia dengan nama Bayur, khususnya di Sulawesi selatan oleh Departemen Kehutanan dikenal dengan nama Banyuru. Bagian kayunya digunakan sebagai bahan untuk pembuatan kayu lapis, furnitur, 
perkapalan, jembatan, pulp dan kertas. Daun dan kulit batang banyak mengandung tanin, yang berkhasiat mengobati gatal-gatal, lobang pada gigi dan sebagai obat disentri.

Menurut Heyne (10), daun Pterospermum celebicum, Miq, dapat digunakan sebagai pewarna dan pemakaiannya sebagai obat tradisional sudah tersebar di seluruh Nusantara, khususnya di Sulawesi Selatan. Para pemakai tumbuhan ini sebagai obat tradisional umumnya berasal dari keluarga ekonomi menengah ke bawah dan kebanyakan digunakan sebagai obat alternatif apabila obat modern tidak lagi efektif.

Dari gambaran senyawa metabolit secara umum pada tumbuhan tingkat tinggi yang mengandung senyawa alami, memiliki potensi untuk mensintesis beberapa senyawa metabolit sekunder (1).

Standardisasi dalam kefarmasian tidak lain adalah serangkaian parameter, prosedur dan cara pengukuran yang hasilnya merupakan unsur-unsur terkait paradigma mutu kefarmasian, mutu dalam artian memenuhi syarat standard (kimia, biologi dan farmasi), termasuk jaminan (batas-batas) stabilitas sebagai produk kefarmasian umumnya.

Standardisasi obat herbal meliputi dua aspek, yaitu aspek parameter spesifik dan aspek parameter non spesifik. Aspek parameter spesifik yakni terutama yang berkaitan dengan senyawa atau golongan senyawa yang mempengaruhi aktivitas farmakologis. Analisis kimia yang dilibatkan ditujukan untuk analisa kualitatif dan kuantitatif terhadap senyawa aktif. Aspek parameter non spesifik berfokus pada aspek kimia, mikrobiologi dan fisis yang akan mempengaruhi keamanan konsumen dan stabilitas, misalnya pengaruh lingkungan tempat tumbuh, adanya pencemar logam berat, pestisida di dalam air dan tanah, kontaminasi selama penanganan pasca panen, peralatan yang digunakan selama proses akan mempengaruhi ada tidaknya dan jumlah bakteri, jamur, pestisida, dan logam berat di dalam ekstrak jika terakumulasi dalam jangka panjang. (9).

Obat tradisional dibuat dalam bentuk ekstrak karena tanaman obat tidak lagi praktis jika digunakan dalam bentuk bahan utuh (simplisia). Ekstrak tersebut bisa dalam bentuk ekstrak kering, ekstrak kental, dan ekstrak cair yang proses pembuatannya disesuaikan dengan bahan aktif yang dikandung serta maksud penggunaannya, apakah dibuat menjadi sediaan dalam bentuk kapsul, tablet, cairan obat dalam, pil, dan lain-lain .

\section{METODE PENELITIAN}

\section{Alat Dan Bahan}

Alat-alat yang digunakan adalah bejana maserasi, orong pisah, labu bersumbat kaca, gelas ukur, pipet tetes, plat tetes,Lampu UV $254 \mathrm{~nm}$ dan $366 \mathrm{~nm}$, Chamber (CAMAG), mikropipet, spektrofotometri UV-VIS (Hewlett-packard $\left.{ }^{\circledR}\right)$,KLT-densitometer ,TLC scanner.

Bahan-bahan yang digunakan adalah alumunium foil, $\mathrm{AlCl}_{3}$, citro borax, $\mathrm{H}_{2} \mathrm{SO}_{4}$, kulit kayu batang, banyuru, etanol $70 \%$, kloroform, kuersetin (Sigma ${ }^{\circledR}$ ), lempeng KLT (silica gel $60 \mathrm{GF}_{254}$ ), Natrium asetat.

\section{Penyiapan Sampel}

Sampel diambil dari daerah Malino. Kulit batang dipisahkan dari batangnya, kemudian dipotong-potong, dikeringkan dalam oven simplisia, selanjutnya dihaluskan dan dilakukan maserasi memakai pelarut etanol $70 \%$.

\section{Penyiapan Ekstrak}

Ekstrak dibuat dengan cara maserasi terhadap serbuk kulit kayu banyuru (Pterospermum celebiqum Miq. ) etanol $70 \%$ LP direndam selama 3 hari. Ekstrak yang diperoleh 
dipisahkan selanjutnya dilakukan remaserasi sebanyak dua kali dengan cara yang sama. Ekstrak dikumpulkan dan diuapkan cairan penyarinya dengan menggunakan rotavapor dan diangin-anginkan sampai diperoleh ekstrak kering

\section{Pemeriksaan organoleptik Ekstrak}

Organoleptik bertujuan sebagai pengenalan awal yang seobyektif mungkin dari ekstrak tanaman meliputi bentuk, bau dan rasa (11). Seperti Tekstur, bau, waran dan rasa.

\section{PenetapanKadar Senyawa yang larut dalam air.}

Sebanyak $5 \mathrm{~g}$ ekstrak dimaserasi dengan $100 \mathrm{ml}$ air-kloroform selama 24 jam,menggunakan labu bersumbat sambil berkali-kali dikocok selama 6 jam pertama dan kemudian dibiarkan selama 18 jam, kemudian disaring. $20 \mathrm{ml}$ filtrat diuapkan hingga kering dalam cawan penguap, residu dipanaskan pada suhu $105^{\circ} \mathrm{C}$ hingga bobot tetap. Dihitung kadar dalam persen senyawa yang larut dalam air terhadap berat ekstrak awal. (7)

\section{Penetapan Kadar Senyawa yang larut dalam etanol}

Sejumlah 5 g ekstrak dimaserasi selama 24 jam dengan $100 \mathrm{ml}$ etanol 96\% menggunakan labu bersumbat sambil berkali-kali dikocok selama 6 jam pertamadan kemudian dibiarkan selama 18 jam.Disaring cepat dengan menghindari penguapan etanol, kemudian diuapkan $20 \mathrm{ml}$ filtrat hingga kering dalam cawan penguap yang telah ditera, residu dipanaskan padasuhu $105^{\circ} \mathrm{C}$ hingga bobot tetap. Dihitung kadar dalam persen senyawa yang larut dalam etanol terhadap berat ekstrak awal. (7)

\section{Kadar Profil Senyawa Kimia dengan KLT}

Larutan uji KLT : Ekstrak etanol $70 \%$ dilarutkan dengan etanol dan dicukupkan volumenya hingga $0,5 \mathrm{ml}$, sehingga larutan stok sampel $20 \mathrm{mg} / 0,5 \mathrm{ml}$.

Prosedur KLT : Untuk melihat spot-spot yang tampak pada masing-masing ekstrak kulit batang kayu banyuru Pterospermum celebiqum Miq. Dilakukan dengan KLT dengan cara : masing-masing larutan sampel dan larutan pembanding (katekin 1\% etanol P) ditotolkan pada lempeng KLT yang sama dengan ukuran 10x10 $\mathrm{cm}$ menggunakan mikropipet sebanyak $5.0 \mu \mathrm{L}, 1 \mathrm{~cm}$ dari dasar lempeng, lalu dibiarkan beberapa saat hingga kering dan dimasukkan ke dalam chamber (bejana kromotografi) yang sudah jenuh dengan cairan pengelusi (fase gerak) Kloroform-metanol 8:2 .Elusi dilakukan sampai batas 0,5 $\mathrm{cm}$ dan tepi atas lempeng. Lempeng dikeluarkan dari bejana dan diangin-anginkan hingga cairan pengelusinya menguap. Dideteksi bercak pada sinar UV 254 dan 366 nm (11).

\section{Penetapan Kadar Flavanoid Total dari Ekstrak Etanol Kulit Kayu Banyuru ditentukan dengan Metode Chang}

\section{a. Pembuatan Larutan Baku Kuersetin}

Ditimbang seksama $10 \mathrm{mg}$ kuarsetin kemudian dilarutkan dalam etanol $80 \%$ dan dicukupkan volumenya hingga $10 \mathrm{ml}$. Sehingga diperoleh larutan stok. Dari larutan stok ini dipipet masing-masing $10 \mu \mathrm{l}, 20 \mu \mathrm{l}, 30 \mu \mathrm{l}, 40 \mu \mathrm{l}, 50 \mu \mathrm{l}$ kemudian ditambah $1 \mathrm{ml}$ etanol $95 \%$, dan $0,1 \mathrm{ml} \mathrm{AlCl} 310 \%$ serta $0,1 \mathrm{ml}$ kalium asetat. Dicukupkan volumenya hingga 5 ml dengan air suling sehingga diperoleh konsentrasi masing-masing 2, 4, 6, 8, dan 10 $\mu \mathrm{g} / \mathrm{ml}$. Selanjutnya diinkubasi selama 25 menit pada suhu kamar. Diukur absorbannya pada panjang gelombang maksimum.

\section{b. Penentuan Flavanoid Total}


Ditimbang seksama kemudian dilarutkan dalam etanol $80 \%$ dan dicukupkan volumenya hingga $10 \mathrm{ml}$, larutan ini diambil 2,5 $\mathrm{ml}$ dan dimasukan dalam labu tentukur $5 \mathrm{ml}$, ditambahkan $0,1 \mathrm{ml} \mathrm{AlCl}_{3} 10 \%$ serta $0,1 \mathrm{ml}$ kalium asetat $1 \mathrm{M}$, dan dicukupkan volumenya dengan air suling. Diukur absorbannya pada panjang gelombang maksimum.

\section{HASIL DAN PEMBAHASAN}

Tabel 1. Hasil Uji Organoleptik Ekstrak etanol kulit batang Banyuru (EKBB) daerah Bantaeng, Malino dan Pare-Pare,

\begin{tabular}{lccccc}
\hline \multirow{2}{*}{ Asal } & Penyari & \multicolumn{4}{c}{ Parameter Organoleptik } \\
\cline { 3 - 5 } & & Bau & Warna & Tekstur & Rasa \\
\hline Bantaeng & Etanol & Spesifik & Coklat tua & Kering & Pahit, Sepat \\
Malino & Etanol & Spesifik & Coklat tua & Kering & Pahit, sepat \\
Pare-Pare & Etanol & Spesifik & Coklat tua & Kering & Pahit, sepat \\
\hline
\end{tabular}

Tabel 2. Hasil perhitungan rendamen (\%) ekstrak etanol kulit batang Banyuru daerah Bantaeng, Malino dan Pare-Pare,dengan menggunakan pelarut air.

\begin{tabular}{llccc}
\hline \multicolumn{1}{c}{ Asal } & Penyari & Berat Simplisia (g) & Berat Ekstrak Etanol (g) & Rendemen $(\%)$ \\
\hline Bantaeng & Etanol & 495 & 59,45 & 12,01 \\
Malino & Etanol & 500 & 61.601 & 12,32 \\
Pare-Pare & Etanol & 480 & 53,85 & 11,22 \\
\hline
\end{tabular}

Tabel 3. Hasil Pengujian kadar air dan kadar abu total dari ekstrak etanol kulit batang Banyuru.

\begin{tabular}{lcc}
\hline \multirow{2}{*}{ Ekstrak Etanol } & \multicolumn{2}{c}{ Persentase } \\
\cline { 2 - 3 } & Kadar air total & Kadar Abu total \\
\hline Bantaeng & $0,0021 \pm 0,0004$ & $0,0201 \pm 0,0004$ \\
Malino & $0,0020 \pm 0,0004$ & $0,0210 \pm 0,0004$ \\
Pare-Pare & $0,0019 \pm 0,0004$ & $0,0191 \pm 0,0004$ \\
\hline
\end{tabular}

Tabel 4. Hasil pengujian kadar senyawa ekstrak etanol kulit batang banyuru daerah Bantaeng, Malino dan Pare-Pare, larut etanol.

\begin{tabular}{ccccccc}
\hline \multirow{2}{*}{ Sampel } & \multicolumn{5}{c}{ Persentase Kadar Senyawa Larut etanol } \\
\cline { 2 - 7 } & $\begin{array}{c}\text { Ekstrak } \\
\text { (gram) }\end{array}$ & $\begin{array}{c}\text { Berat } \\
\text { Cawan } \\
\text { (gram) }\end{array}$ & $\begin{array}{c}\text { Berat Akhir } \\
\text { cawan } \\
\text { (gram) }\end{array}$ & $\begin{array}{c}\text { Berat Larut } \\
\text { Etanol } \\
\text { (gram) }\end{array}$ & $\begin{array}{c}\text { Persentase } \\
(\%)\end{array}$ & $\begin{array}{c}\text { Rentang } \\
\text { Rata-rata } \\
(\%)\end{array}$ \\
\hline Bantaeng & 1.001 & 22.625 & 23.626 & 0.13 & 1.299 & $13,482 \pm 0,036$ \\
& 1.002 & 22.400 & 23.402 & 0.135 & 1.347 & \\
Malino & 1.001 & 22.360 & 23.3609 & 0014 & 1.399 & \\
& 1,000 & 22.360 & 23.360 & 0,147 & 1.470 & $14,895 \pm 0,040$ \\
& 1.001 & 22.361 & 23.3614 & 0.150 & 1.499 & \\
& 1,001 & 22.350 & 23.350 & 0.150 & 1.500 & \\
Pare-Pare & 1.003 & 20.244 & 21.247 & 0.147 & 1.466 & $14,762 \pm 0.007$ \\
& 0.999 & 20.245 & 21.244 & 00148 & 1.481 & \\
& 0.999 & 20.245 & 21.244 & 0.148 & 1.482 & \\
\hline
\end{tabular}


Tabel 5. Hasil pengujian kadar senyawa ekstrak etanol kulit batang Banyuru daerah Bantaeng, Malino dan Pare-Pare, larut air.

\begin{tabular}{lcccccc}
\hline & \multicolumn{5}{c}{ Persentase Kadar Senyawa Larut Air } \\
\cline { 2 - 7 } Sampel & $\begin{array}{c}\text { Ekstrak } \\
(\text { gram) }\end{array}$ & $\begin{array}{c}\text { Berat } \\
\text { Cawan } \\
\text { (gram) }\end{array}$ & $\begin{array}{c}\text { Berat Akhir } \\
\text { cawan } \\
(\text { gram })\end{array}$ & $\begin{array}{c}\text { Berat } \\
\text { Larut Air } \\
(\text { gram })\end{array}$ & $\begin{array}{c}\text { Persentase } \\
(\%)\end{array}$ & $\begin{array}{c}\text { Rentang } \\
\text { Rata-rata } \\
(\%)\end{array}$ \\
\hline Bantaeng & 1,0008 & 23,771 & 24,772 & 0,018 & 1,798561 & $1,842 \pm 0,051$ \\
& 1,0007 & 23,951 & 24,952 & 0,018 & 1,808734 & \\
Malino & 1,0008 & 23,961 & 24,962 & 0,019 & 1,918465 & \\
& 1,0010 & 23,770 & 24,771 & 0,037 & 3,696304 & $3,613 \pm 0,078$ \\
& 1,0012 & 23,771 & 24,772 & 0,036 & 3,645625 & \\
Pare- & 1,0010 & 23,780 & 24,781 & 0,035 & 3,496503 & \\
Pare & 1,0009 & 23,260 & 24,261 & 0,025 & 2,497752 & $2,485 \pm 0,031$ \\
& 1,0008 & 23,261 & 24,261 & 0,024 & 2,43805 & \\
\hline
\end{tabular}

Gambar 1 Hasil Foto KLT pada sinar UV dengan panjang $366 \mathrm{~nm}$ gelombang 200$800 \mathrm{~nm}$, Cairan pengembang yang digunakan adalah butanol:asam asetat:air (4:1:5). a.) Ekstrak Etanol Banyuru Bantaeng. b.) Ekstrak Etanol Banyuru Malino c.) Ekstrak Etanol Banyuru Pare-Pare.

Gambar 2. Senyawa Kimia Plat KLT Dengan menggunakan KLT- Desitofotometer pada sinar UV dengan panjang gelombang 200-800 nm, Cairan pengembang yang digunakan adalah butanol:asam asetat:air (4:1:5). a.) Ekstrak Etanol Banyuru Bantaeng. b.) Ekstrak Etanol Banyuru Malino c.) Ekstrak Ekstrak Etanol Banyuru Pare-Pare.

\section{Pembahasan}

Pada saat disemprot dengan sitroborat akan terjadi ikatan kompleks pada gugus ortohidroksi dan menimbulkan pergeseran khas pada pita panjang gelombang yang lebih 
besar yang berguna pada analisis beberapa golongan flavonoid. Nilai Rf ekstrak tidak jauh berbeda dengan noda, sehingga dapat dinyatakan bahwa ekstrak etanol memiliki kandungan senyawa flavonoid, yang dapat dilihat pada gambar 1 sampai 5

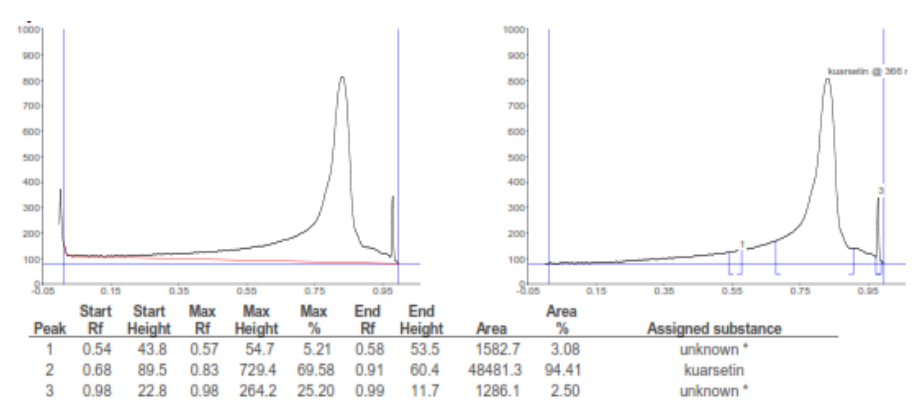

Gambar 3.Hasil profil kromatogram ekstrak etanol Kulit Batang Banyuru Bantaeng pada panjang gelombang $254 \mathrm{~nm}$. Fase gerak metanol:air (2:1). Fase diam Oktadesil silika (ODS).

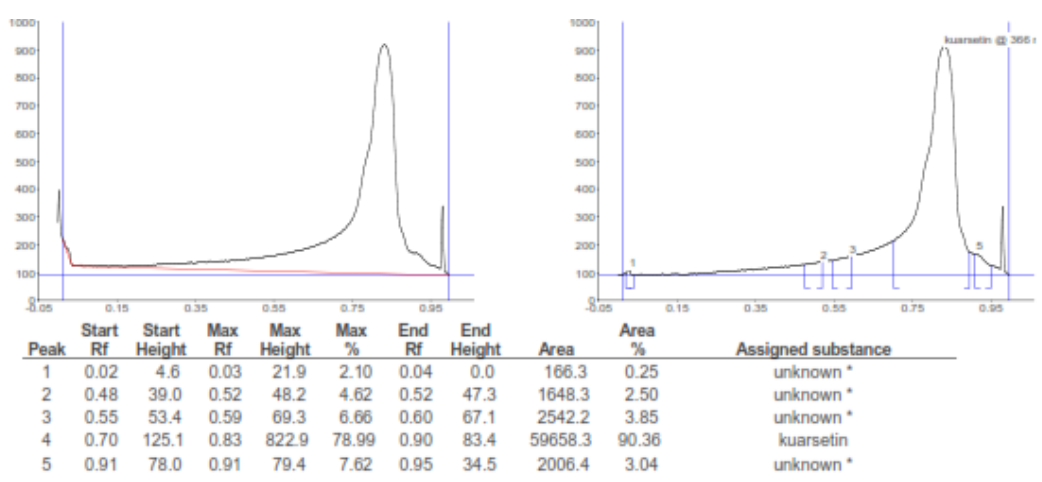

Gambar 4.. Hasil profil kromatogram ekstrak etanol Kulit Batang Banyuru Malino pada panjang gelombang $254 \mathrm{~nm}$. Fase gerak metanol:air (2:1). Fase diam Oktadesil silika (ODS).

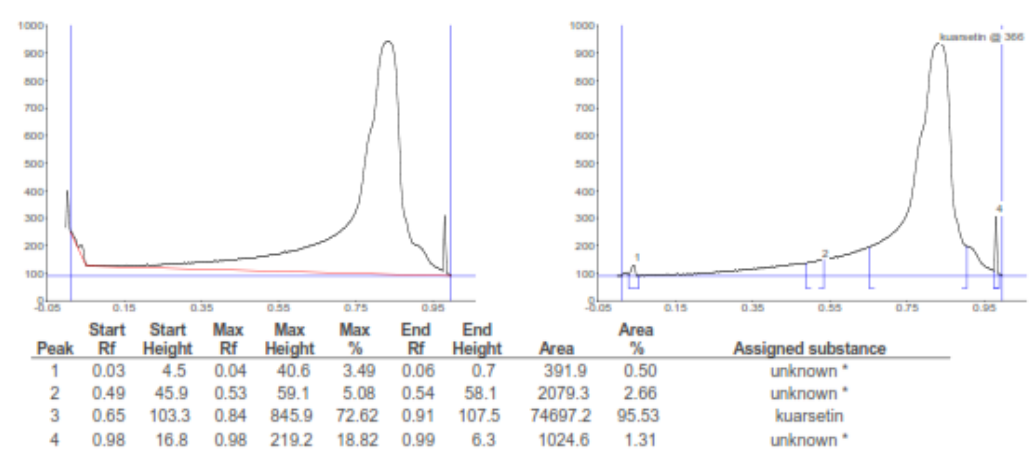

Gambar 5. Hasil profil kromatogram ekstrak etanol Kulit Batang Banyuru Pare-Pare pada panjang gelombang $254 \mathrm{~nm}$. Fase gerak metanol:air (2:1). Fase diam Oktadesil silika (ODS).

Kadar air ekstrak kering $<5 \%$, ekstrak kental 5-30\%, dan ekstrak cair $>30 \%$. Tujuan dari parameter susut pengeringan adalah memberikan batasan maksimal (rentang) tentang 
besarnya air ataupun pelarut lain yang hilang pada proses pengeringan. Kulit Batang Banyuru (Pterospermum celebicum, Miq ) mengandung tanin (6), Polifenol, Terpenoid, Flavonoid. Pada profil KLT-densitometri (12), memakai eluen butanol:asam asetat:air (4:1:5) menunjukkan beberapa titik puncak yang hampir sama dari ketiga sampel yaitu, dengan eluen metanol:air (2:1), titik puncak yang sama, bahwa kesamaan profil ini menunjukkan pada ekstrak etanol asal Bantaeng, Malino dan Pare-Pare mengandung senyawa kimia identik yaitu senyawa flavonoid.dengan pembanding quersetin.Kadar Flavonoid Total yang terkandung dalam ekstrak etanol kulit batang Banyuru (Pterospermum celebiqum Miq.) asal Bantaeng, Malino dan Pare-Pare. memakai metoda spektrofotometrk UV/Vis, dapat dilihat pada tablel 6.

Tabel 6. Hasil Pengukuran Kadar Flavonoid Total Ekstrak Etanol Banyuru (Pterospermum celebiqum Miq.) Asal Bantaeng, Malino dan Pare-Pare.

\begin{tabular}{lcccc}
\hline Asal & $\begin{array}{c}\text { Bobot } \\
\text { Ekstrak } \\
(\mathrm{ppm})\end{array}$ & $\begin{array}{c}\text { Serapan } \\
(\mathrm{A})\end{array}$ & $\begin{array}{c}\text { Kadar Total } \\
\text { Flavonoid } \\
(\%)\end{array}$ & $\begin{array}{c}\text { Kadar rata-rata } \\
\text { Flavonoid Total } \\
(\%)\end{array}$ \\
\hline Bantaeng & 500 & 0,651 & 1,099 & $1,100 \pm 0,001$ \\
& & 0,651 & 1,099 & \\
Malino & 500 & 0,652 & 1,100 & \\
& & 0,612 & 1,068 & $1,068 \pm 0,001$ \\
Pare-Pare & 500 & 0,612 & 1,068 & \\
& & 0,603 & 1,067 & \\
& & 0,602 & 1,046 & $1,046 \pm 0,001$ \\
& & 0,603 & 1,046 & \\
\hline
\end{tabular}

\section{KESIMPULAN DAN SARAN}

\section{KESIMPULAN}

Berdasarkan hasil penelitian yang telah dilakukan dapat disimpulkan :

1. Penentuan organoleptik ekstrak, menunjukkan bahwa ekstrak etanol EKBB memiliki bau yang khas, bertekstur serbuk, berwarna coklat tua dan memiliki, ,rasa sepat dan pahit.

2. Kadar senyawa ekstrak yang terlarut dalam pelarut tertentu menunjukkan bahwa kadar senyawa ekstrak EKBB Bantaeng Kadar yang larut air 13,48\% dan kisaran kadar senyawa larut etanol 1,84\%. kadar senyawa ekstrak EKBB asal Malino larut air $14,89 \%$ dan kisaran kadar senyawa yang larut etanol 3,61\%. kadar senyawa ekstrak EKBB asal Para-Pare yang larut air 14,76\% dan kadar senyawa larut etanol $1,05 \%$.

3. Kandungan senyawa kimia ekstrak EKBB asal Bantaeng, Malino dan Pare-Pare merupakan senyawa golongan flavonoid.

4. Kadar Flavonoid total ekstrak EKBB Bantaeng adalah 1,10\%, kandungan flavonoid ekstrak EKBB Malino yaitu 1,06\% dan total kandungan flavonoid ekstrak EKBB Pare-Pare yaitu $1,05 \%$ sebagai kuersetin.

5. Profil KLT - Densitometri ekstrak EKBB, diperoleh senyawa yang muncul, pada spot yaitu spot 1 , spot 2 dan spot 3 .

\section{SARAN}


Perlu dilakukan uji kandungan total senyawa epikatecin, tanin, alkaloid, minyak menguap, asam prusid, dan triterpenoid untuk memperoleh data standar yang lengkap tentang EKBB.

\section{DAFTAR PUSTAKA}

1. Manitto, P. 1981. Biosynthesis of Natural Product. John Wiley \& Sons New York Robinson, T. 1991. The Organic Constituens Of Higher Plants, 6 th Edition Departement Of Biochemistry University of Massachusett , Amherst, MA 01003, 9671.

2. Bisset, N. G. 1955. A phytochemical Survey Of Some Plants From The South Moluccas. Treub laboratory. Kebun Raya Bogor. 137.

3. Silbinol. S. C., 2000, A Rich Sources OF Polyphenolic Compounds Of Pterospermum marsupium, Phytochemistry Sabinsa Corporation, 70

4. Camporese, A., Balick, M.J., Arvigo, R., Esposito, R. G., Morsellino, N., De Simone, F, A. 2003. Screening Of Anti Bacterial Activity Of Medicinal Plants From Belize (Central America).Journal Of Etnopharmacology 87(2003):103 - 107.

5. Stalikas, D.C. Extraction, Separation, and Detection Method for Phenolic Acid and Flavonoid. Journal Sep. Sci. 2007. Hal. 30, 3268-3295

6. Sossef, M. S., M.,Hong,L.T. and Prawirohatmodjo,S. 1998. Plant Resources of South - East Asia No 5 (3). Prosea Bogor Indonesia 479-482.

7. Saifudin, A., Rahayu, V., dan Teruna, HY. Standardisasi Bahan Obat Alam. Graha Ilmu. Jakarta. 2011. hal. 1-4, 69.

8. Departemen Kesehatan RI, (2000), Parameter Standar Umum Ekstrak Tumbuhan Obat, EdisiI, Direktorat Jenderal Pengawasan Obat dan Makanan,Direktorat Pengawasan ObatTradisional, Bakti Husada,Jakarta, Hal.1-56, 18- 29

9. Hariyati, S. Standardisasi Ekstrak Tumbuhan Indonesia, Salah Satu Tahapan Penting Dalam Pengembangan Obat Asli Indonesia. 2005. Available from: Majalah InfoPOM Volume 6 Nomor 4 Juli 2005. hal. 1-5.

10. Heyne,K,. Tumbuhan berguna Indonesia. Jilid III, Terjemahan oleh Balitbang Kehutanan. Yayasan Sarana Warna aya: Jakarta. 1987. Hal. 1352-1353.

11. Harborne, J.B. 1987.Metode Fitokimia. Terjemahan oleh Padmawinata K \&Soediro I.Bandung. Penerbit ITB. Hal. 120

12. Shukla, S.S.,Swarnlata S.,dan Shailendra S. TLC densitometric 